\title{
MICROLEARNING KOPERASI DAN UMKM: PENINGKATAN KOMPETENSI AKUNTANSI MELALUI APLIKASI PERSEDIAAN GOOGLE PLAYSTORE "CATATAN KEUANGAN KOPERASI" DAN APLIKASI MS EXCEL
}

\section{Microlearning Cooperatives And Msmes: Increasing Accounting Competence Through The Google Playstore Inventory Application "Cooperative Financial Record" And Ms Excel Application}

\section{Gusti Ketut Agung Ulupui , Etty Gurendrawati, Siti Fatimah Zahra, Indra Pahala, Yunika Murdayanti}

${ }^{1}$ Program Studi Akuntansi Fakultas Ekonomi Universitas Negeri Jakarta

\author{
Jl. Rawamangun Muka No. 1 Jakarta Timur
}

Alamat korespondensi: Igka-Ulupui@unj.ac.id

(Tanggal Submission: 13 July 2021, Tanggal Accepted : 19 Agustus 2021)

\begin{abstract}
Kata Kunci : $\quad$ Abstrak :
persediaan barang dagang, aplikasi android, aplikasi ms.excell, microlearning, koperasi/UMKM

Selama masa pandemi COVID 19 ini, provinsi Jawa Barat berupaya untuk mendorong kembali kegiatan ekonomi masyarakat dengan melakukan penataan pencatatan persediaan bahan baku sehingga dapat menaikkan kembali omset penjualan. Persediaan memainkan fungsi yang sangat penting dalam kelangsungan hidup serta perkembangan bisnis. Manajemen persediaan yang tidak efektif dan efisien dapat menyebabkan kerugia dan penyusutan penjualan. Tujuan kegiatan pengabdian masyarakat ini adalah: 1) Dipahaminya konsep-konsep dalam pengendalian persediaan terutama dalam pencatatan bahan baku dan barang jadi, 2) Dilaksanakannya microlearning mengenai penggunaan aplikasi smart apps terdaftar pada google play store "catatan keuangan koperasi" dan aplikasi pencatatan persediaan menggunakan ms. excelll yang bertujuan untuk meningkatkan kompetensi peserta. Metode pelaksanaan Pengabdian pada Masyarakat ini dilakukan secara daring melalui aplikasi zoom meeting dengan peserta pengelola koperasi/UMKM serta turut mengundang para mitra koperasi dan UMKM dari Departemen Ekonomi, Pembina Daerah Salima Kota Bogor dan Perwakilan Mitra UMKM Kota Depok. Kegiatan ini mampu menghasilkan peningkatan kompetensi koperasi dan UMKM dalam pengendalian persediaan, mampu menghitung laporan keuntungan, dan mampu mempraktekan aplikasi pencatatan persediaan baik berbasis android maupun ms. excelll sehingga para pelaku usaha mampu membuat pencatatan persediaan secara digitalisasi.
\end{abstract}

Panduan sitasi / Citation guidance (APPA $7^{\text {th }}$ edition) :

Ulupui, I. G. K. A., Gurendrawati, A., Zahra, S.F., Pahala, I., \& Murdayanti. Y. (2021). Microlearning Koperasi Dan Umkm: Peningkatan Kompetensi Akuntansi Melalui Aplikasi Persediaan Google Playstore "Catatan Keuangan Koperasi" Dan Aplikasi Ms Excel. Abdi Insani, 8 (2), 223235. http://doi.org/10.29303/abdiinsani.v8i2.405 


\section{PENDAHULUAN}

Pengembangan model yang mendemonstrasikan pemanfaatan microlearning menggambarkan penyampaian konten pembelajaran dalam sesuatu panduan ataupun materi yang berdiri sendiri serta pendek. Tiap materi secara komprehensif mangulas satu tujuan pendidikan memanfaatkan video, bacaan, foto, serta/ ataupun audio (Dolasinski \& Reynolds, 2020). Faedah dari pendekatan ini adalah mempersingkat, memfokuskan, serta menambah ketersediaan pelatihan. Penyelenggaraan microlearning ini menggambarkan program pendidikan yang seluruhnya dilaksanakan secara online, yang bertujuan membuat keberhasilan pemahaman dan kompetensi partisipan menjadi lebih baik. Pada realitasnya e-learning tidak senantiasa membuat proses belajar berjalan maksimal, terkadang sebagian tujuan dari belajar itu sendiri tidak bisa dicapai. Berdasarkan hal tersebut, menyajikan suatu modul ataupun konten dalam e-learning menjadi suatu tantangan yang wajib jadi atensi, dalam hal ini yaitu upaya untuk menciptakan suatu strategi yang menjadi pemecahan dalam menyajikan konten yang baik, menarik serta mudah untuk para partisipan di tengah banyak kendala yang mampu mengalihkan perhatian dan fokus dikala belajar. Dikarenakan perihal tersebut, timbul strategi baru yakni microlearning yang digadang-gadang bisa menolong para pelajar dalam menggapai tujuan belajarnya melalui e-learning. Sedangkan, microlearning sendiri merupakan tata cara pengajaran baru tanpa definisi spesial, yang terpaut erat dengan e-learning. Microlearning menempatkan pengetahuan dalam pecahan kecil serta bisa dipahami.

Saat ini, hampir setiap orang yang memanfaatkan internet mendapatkan manfaat dari Microlearning yang artinya Googling, memeriksa email, membaca, dan menonton konten web di Internet. Menariknya, perangkat seluler pintar memungkinkan kami memanfaatkan rilis informasi terbaru juga. Microlearning memberi peserta didik untuk mengakses informasi terbaru kapanpun, dimanapun, dan dalam format yang mereka butuhkan. Selain itu, karena fitur yang tersedia, dalam metode Microlearning kecepatan belajar dipilih sendiri oleh siswa. Mereka dapat mengakses konten yang dipelajari sebanyak yang mereka suka dengan kecepatan yang mereka inginkan. Oleh karena itu, metode Microlearning dapat membekali siswa dengan pengetahuan dan keterampilan yang dibutuhkan yang mereka butuhkan saat mereka menemukan jalan dalam kehidupan individu mereka (Mohammed et al., 2018). Model pembelajaran mikro yang diusulkan menggabungkan teori pembelajaran yang teruji dan menangani kekhawatiran mengenai kebutuhan siswa yang berkembang di tempat kerja. Model dapat dibagi menjadi empat tahap: (1) pra-pengembangan pembelajaran; (2) pengembangan dan penyampaian konten pembelajaran; (3) partisipasi, praktik, dan demonstrasi pelajar; dan (4) evaluasi. Microlearning adalah pendekatan pembelajaran yang menyampaikan informasi tentang satu ide spesifik dengan cara yang kompak dan terfokus. Ini menunjukkan perlunya momen pembelajaran cepat untuk membantu memfasilitasi perubahan perilaku karyawan dan mempertahankan keunggulan kompetitif organisasi. Dengan banyaknya format media di ujung jarinya, pembelajaran mikro pada aplikasi seluler melibatkan dan mendukung gaya belajar yang beragam (Shail, 2019).

Koperasi membutuhkan upaya mempertahankan bisnisnya demi kelangsungan usahanya, tetapi yang kerap terjadi yaitu manajemen persediaannya tidak mampu dikelola dengan baik sehingga selalu mengalami keadaan kerugian. Hal ini menyebabkan pengelolaan koperasi yang tidak efisien serta efektif dan kadang- kadang menimbulkan berbagai pengeluaran persediaan yang besar namun harus selalu menaati dan menjalankan prinsip koperasi sesuai yang dicantumkan dalam UU Nomor12 Tahun 1967 dan UU Nomor 25 Tahun 1992 (Kader, 2018; Lestari \& Kholil, 2018). Tujuan dari 
pengelolaan koperasi ini merupakan suatu upaya untuk meminimalisir biaya- biaya operasional sekecil mungkin sehingga tercapai fungsi memaksimalkan kinerja organisasi. Persediaan memainkan kedudukan yang berarti dalam kelangsungan hidup serta perkembangan bisnis dalam makna bahwa manajemen persediaan yang tidak efektif dan efisien akan mampu menyiratkan suatu kondisi dalam organisasi yang mengalami pengurangan jumlah pelanggan dan berdampak pada menyusutnya jumlah penjualan (Sari, 2018). Pengendalian persediaan mengaitkan pada adanya jumlah ketersediaan bahan, penggunaan, pengawasan dan pasokan bahan. Pengendalian persediaan merupakan gabungan kegiatan dengan tujuan utama untuk memperoleh persediaan yang sesuai di tempat yang sesuai, pada waktu yang sesuai, serta dalam jumlah yang sesuai. Tidak hanya itu, terpaut langsung dengan kegunaan penciptaan organisasi yang berarti jika sistem manajemen persediaan dilaksanakan baik secara langsung ataupun tidak langsung dapat mempengaruhi keuntungan usaha (Khan et al., 2019). Dengan kata lain, manajemen persediaan adalah perihal yang berperan penting dan wajib dicermati dalam suatu organisasi atau industri (Putra \& Purnawati, 2018). Manajemen persediaan menyangkut mengenai tata cara dalam organisasi untuk mampu mengatur persediaannya dan dapat melakukan aktivitas yang berhubungan dengan pemasukan, penyimpanan, pemeliharaan, serta pendistribusian persediaan dari hasil kebutuhan dan penyimpanan persediaan itu sendiri (Lutfiana \& Puspitosari, 2020). Begitu pula pada Usaha Mikro dan Kecil (UMK) memiliki kepentingan strategis di negara berkembang yang berkontribusi pada pendapatan nasional, lapangan kerja, ekspor, dan pengembangan kewirausahaan. Pengembangan UMK adalah fokus utama dari strategi pengembangan industri yang dinyatakan dalam Rencana Pertumbuhan dan Transformasi (GTP). Hal ini diperoleh berdasarkan literatur terdahulu mengenai pemanfaatan aplikasi manajemen persediaan resmi yang merupakan salah satu metode guna mendapatkan daya saing (Atnafu \& Balda, 2018).

\section{Permasalahan Mitra}

Aspek Pengelolaan Manajemen pada Pencatatan Persediaan

Metode ini menunjukkan bahwa persediaan dengan nilai akuisisi awal (pertama) akan dijual (digunakan) pertama kali, sehingga nanti saat persediaan akhir akan dievaluasi dengan nilai persediaan baru atau yang terakhir (dibeli). Berkenaan dengan ini, maka tim pengabdian pada masyarakat ini berasumsi bahwa sangat perlu untuk melakukan transfer pengetahuan melalui pembelajaran online berupa pemaparan konsep dan pelatihan terhadap kasus-kasus terkini, dan yang paling berhubungan dengan pengelolaan manajemen para pelaku koperasi dan UMKM, sehingga tercapai suatu koperasi yang lebih maju dan bermanfaat tidak hanya untuk anggota, tetapi juga masyarakat sekitar.

\section{Aspek Teknologi Informasi}

Anggota koperasi dan UMKM harus di training untuk lebih tanggap dan siap menjadi seorang wirausahawan yang tangguh. Upaya perintisan ini juga harus dimulai tidak hanya untuk dibahas atau diucapkan secara lisan saja. Optimis terhadap diri sendiri dengan mengabaikan perasaaan akan takut terhadap kegagalan, memperluas perkenalan atau network, serta menggunakan teknologi informasi dalam pelaksanaan setiap usaha. Anggota koperasi dan UMKM juga diundang untuk menggunakan teknologi informasi sebagai peluang bisnis dalam mendirikan usaha memperluas jaringan yang penggunaannya relatif mudah. Telah ditunjukkan bahwa teknologi informasi memberikan kesempatan untuk membangun bisnis secara efisien dan memberikan manfaat yang sangat besar di saat semua para pelaku usaha tertimpa dampak kerugian akibat pandemi covid 19. Sangatlah berguna 
seorang pelaku usaha memiliki semangat kewirausahaan yang tinggi dengan menghilangkan prestise, tetapi memiliki tingkat optimisme yang tinggi.

Berdasarkan analisis situasi sebelumnya dan hasil wawancara penelitian sebelumnya, diperoleh hasil dari masalah mitra:

1. Manajemen administrasi dalam persediaan masih tetap rendah dengan ditunjukkan oleh indikator kurangnya akuntabilitas/pertanggungjawaban dan penggunaan catatan keuangan yang masih manual serta didukung dengan dana yang terbatas.

2. Pengetahuan pendidikan bisnis atau kewirausahaan yang minimalis mengakibatkan kurangnya keterampilan untuk menjadi wirausahawan yang berani.

3. Jumlah pemasukkan dan biaya persediaan tidak seimbang.

4. Kurangnya pengetahuan dalam memahami manajemen persediaan dan akuntansi persediaan.

5. Kurangnya pekerja terampil dan ahli dalam bidang persediaan.

Tujuan kegiatan pengabdian kepada masyarakat ini adalah memberikan pengetahuan dan pemahaman bagi para koperasi dan UMKM tentang teori dan konsep persediaan baik dalam manajemen persediaan dan akuntansi manajemen dan praktek pencatatan persediaan melalui aplikasi berbasis android yang terdaftar pada google playstore "catatan keuangan koperasi" dan aplikasi pencatatan persediaan dengan menggunakan ms. excell. Hasil dari kegiatan pengabdian pada masyarakat ini memberikan manfaat peningkatan pengetahuan dan pemahaman para pelaku Koperasi dan UMKM dalam teori-teori persediaan, bermanfaat dalam memahami pengendalian persediaan terutama membuat pencatatan jumlah persediaan yang rapi dengan menggunakan aplikasi berbasis digital dan mampu mengetahui jumlah laporan keuntungan dari jumlah persediaan masuk dan persediaan keluar secara periodik sehingga dapat dengan mudah mengetahui omset penjualan yang diperoleh selama harian dan bulanan.

\section{METODE KEGIATAN}

Tahapan Pelaksanaan Kegiatan

Pelaksanaan kegiatan pengabdian ini mengikuti pelaksanaan kegiatan penelitian tindakan, yang terdiri dari perencanaan, persiapan, pelaksanaan, observasi dan evaluasi serta refleksi.

a. Perencanaan

1. Koordinasi dengan LPPM Universitas Negeri Jakarta

2. Sosialisasi kegiatan pengabdian kepada koperasi dan UKM terkait

3. Pengembangan program pengabdian pada masyarakat ini dilaksanakan berdasarkan hasil analisis situasi, analisis sumber daya manusia pengelola koperasi dan UMKM, jenis pencatatan keuangan, pendapatan dan pengeluaran, inventarisasi, analisis materi kewirausahaan, dan pengembangan TI melalui Microlearning.

b. Pelaksanaan Aksi

1. Pembentukan dan dukungan kelompok pengurus koperasi dan para UMKM yang dapatmengendalikan kendala dalam pencatatan persediaan

2. Pelatihan pengelolaan persediaan melalui sistem metode pencatatan persediaan FIFO

3. Menguasai praktek pendapatan dan pengeluaran serta pencatatan yang sesuai dengan jumlah barang

4. Mendemonstrasikan penggunaan perangkat lunak aplikasi teknologi informasi digital terdaftar di google playstore "catatan keuangan koperasi" dan ms excell dalam metode pembelajaran online (microlearning).

c. Observasi dan Evaluasi

Pengawasan pembelajaran secara online ini dilakukan langsung oleh para tim pelaksana pengabdian pada masyarakat. Observasi terdiri dari bukti kuesioner dan hasil diskusi selama pelatihan. 
Proses evaluasi dilakukan untuk mengidentifikasi kekurangan dan hambatan dalam pelaksanaan kegiatan pelatihan.

d. Refleksi

Refleksi dilakukan secara bersama-sama antara tim dan peserta untuk mengetahui keseluruhan proses pelaksanaan kegiatan.

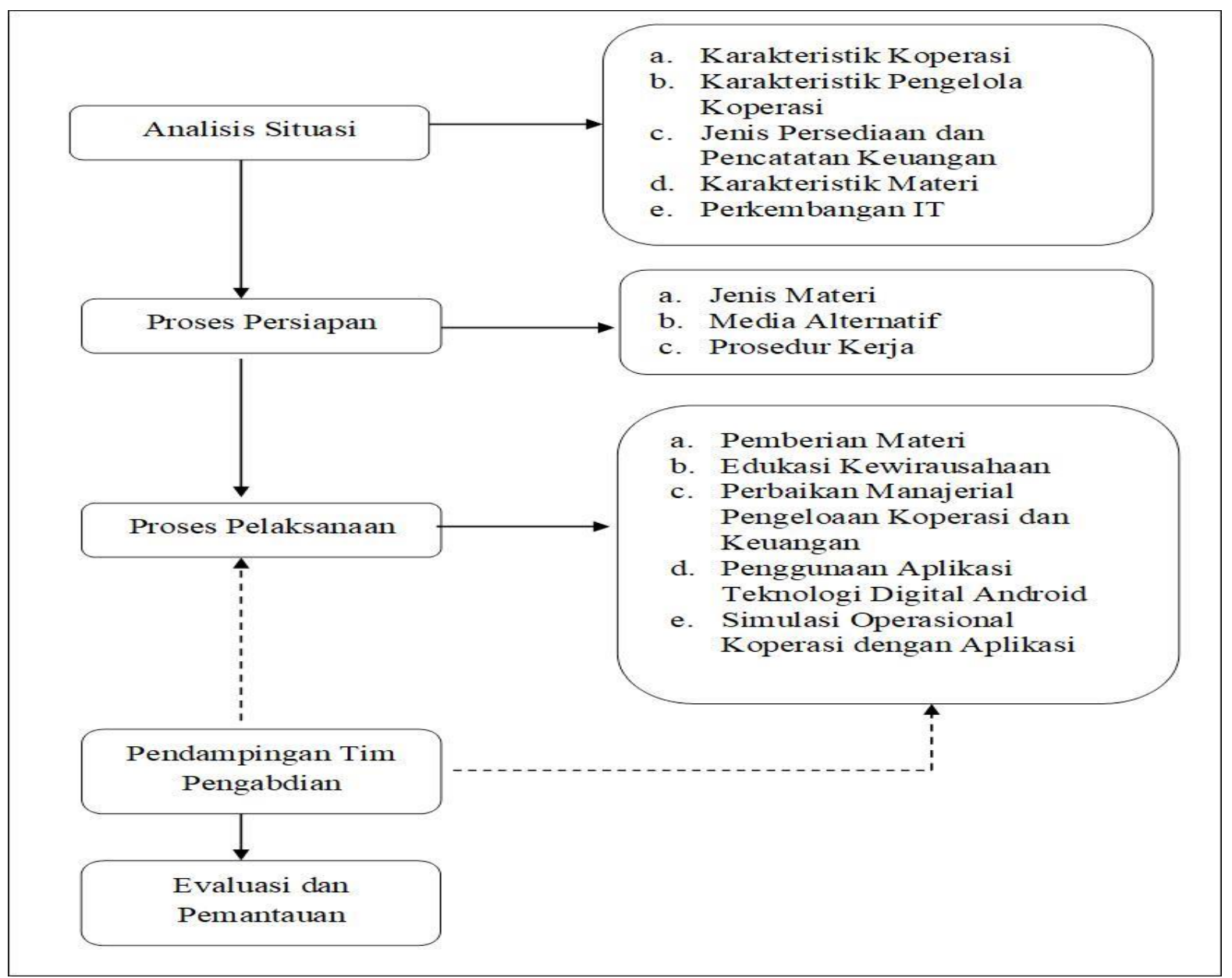

Gambar 1 Skema Kegiatan PKM

Metode Pendekatan yang Ditawarkan

Transfer ilmu pengetahuan dan teknologi oleh tim dalam setiap fase yang diterima oleh mitra berlangsung melalui proses mendengarkan, mengetahui, mencoba, mengevaluasi, menerima, mempercayai dan menerapkan yaitu:

1. Wawancara dengan pengurus koperasi dan UMKM yang bersedia melakukan perbaikan dalam mengelola keuangannya agar lebih efektif dan efisien.

2. Ceramah dalam pembelajaran online mengenai manajemen persediaan.

3. Diskusi dilakukan dalam pembelajaran sebagai upaya mengetahui umpan balik tentang catatan keuangan para pelaku usaha disertai penunjukkan bukti yang berurutan dan hambatan dalam mengatur keuangan.

4. Pelatihan microlearning mengenai persediaan menggunakan aplikasi cerdas, dengan tujuan agar seluruh inventaris dicatat hingga menjadi laporan laba rugi yang dapat diketahui secara periodik.

Partisipasi mitra dalam pelaksanaan program 
Koperasi dan para pelaku UMKM yang menjadi mitra dalam kegiatan ilmiah dan teknologi ini mengambil bagian aktif dalam semua kegiatan yang dilakukan. Sementara itu, dalam kegiatan pembelajaran online ini, selain berpartisipasi sebagai peserta, para mitra berperan untuk berpartisipasi mensosialisasikan program pelatihan microlearning ini dan mendukung pelaksanaan program kegiatan IPTEKS ini secara keseluruhan.

Rancangan Evaluasi Pelaksanaan Program dan Keberlanjutan Program

Tujuan dari rencana evaluasi kegiatan ini adalah untuk menilai penguasaan pengurus koperasi dan UMKM terhadap materi pelatihan, pelaksanaan kegiatan dan dampak kegiatan. Rencana evaluasi dirinci untuk seperti di bawah ini:

1. Peningkatan manajemen koperasi dan UMKM yang bertujuan untuk memperoleh kondisi keuangan yang baik.

2. Meningkatkan keuletan dan ketelitian dalam menghitung jumlah persediaan dan pencatatan keuangan.

3. Peningkatan kreativitas

4. Kemampuan untuk melakukan pengelolaan persediaan menggunakan aplikasi yang relatif mudah demi keberlangsungan usaha.

\section{HASIL DAN PEMBAHASAN}

\section{Deskripsi Kegiatan}

Kegiatan pelatihan yang dilaksanakan oleh Universitas Negeri Jakarta ini merupakan salah satu bentuk pengabdian pada masyarakat dan bertujuan untuk mengatasi hambatan yang dihadapi oleh para koperasi dan UMKM dalam hal yang berhubungan pengelolaan persediaan. Pengabdian kepada masyarakat juga merupakan salah satu tugas seorang dosen dalam mewujudkan Tridharma Perguruan Tinggi dan dilakukan secara rutin per tahunnya. Pengabdian kepada Masyarakat oleh Universitas Negeri Jakarta ini telah dilaksanakan pada tanggal 30 Juni 2021 yang menggunakan fitur media pembelajaran secara online dan diikuti oleh pengurus dari koperasi dan para pelaku UMKM. Tema yang diangkat pada pelaksanaan pengabdian pada masyarakat ini adalah "'Microlearning Koperasi dan UMKM: Peningkatan Kompetensi Akuntansi melalui Persediaan Smart Apps". Pelatihan ini diisi oleh 3 orang narasumber dan dibantu oleh tim panitia.

Secara garis besar tujuan dari pembelajaran ini merupakan bentuk partisipasi dalam menjawab perubahan perkembangan teknologi informasi yang merupakan kendala bagi para koperasi dan UMKM di Indonesia dikarenakan minimnya pengetahuan dan terutama kendala memiliki koneksi internet yang stabil. Sedangkan kesulitan lainnya adalah menjaga agar inventaris atau persediaan yang dimiliki para UMKM ini bisa bervariasi (banyak pilihan) tanpa adanya kerusakan dan menghindari jangka waktu kadaluwarsa suatu persediaan yang dapat merugikan pelanggan. Koperasi dan para pelaku UMKM sebaiknya melakukan pendokumentasian data inventaris atau, tanpa kecuali, mencatat semua persediaan barang dagang yang masuk dan keluar. Oleh karena itu, para pelaku UMKM dapat selalu mengetahui berapa banyak persediaan yang mereka miliki / masih ada di dalam gudang.

Pelatihan microlearning yang dilaksanakan secara online ini berlangsung selama 1 hari, yaitu pada hari Rabu, 30 Juni 2021 dari jam 8 pagi sampai jam 1 siang WIB. Fokus pelatihan ini adalah mengetahui sejauh mana para peserta mendapatkan pemahaman dan keterampilan terkait pengelolaan keuangan khususnya pengetahuan dalam pengelolaan persediaan. Materi pelatihan ini terbagi menjadi 3 diskusi yang terdiri dari: 1) Diskusi 1 tentang Teori dan Inventarisasi Koperasi, 2) Diskusi 2 tentang Aplikasi Pemesanan Inventaris dengan Smartphone atau Aplikasi Pemesanan Keuangan Koperasi Berbasis Android yang Terdaftar di Google Playstore, dan 3) Diskusi 3 tentang Menggunakan Pencatatan Persediaan dengan Microsoft Excell.

\section{Analisis Teoritits}

Sesi 1 merupakan sesi materi presentasi menjelaskan teori, manajemen persediaan dan akuntansi persediaan dengan maksud untuk mencatat secara berkala kegiatan usaha koperasi dan 
UMKM. Materi ini disajikan dalam bentuk ceramah, dilanjutkan dengan sesi tanya jawab. Sesi 2 menggunakan teknik praktis dan simulasi masalah persediaan sederhana. Materi ini menjelaskan langkah-langkah yang terlibat dalam membuat daftar persediaan, saldo persediaan, daftar pemasok, daftar pelanggan, catatan penerimaan, dan laporan biaya persediaan yang dapat dilaporkan secara berkala. Peserta akan mendapatkan contoh transaksi dan dilatih menggunakan aplikasi berbasis android yanng dapat diunduh di google playstore. Berikut menu-menu dalam aplikasi catatan keuangan koperasi yang tertera pada aplikasi terdaftar di google playstore yaitu:

1. Daftar stok, adalah salah satu menu yang bermanfaat dalam memasukkan jumlah-jumlah persediaan yang dimiliki oleh para pelaku usaha dan juga dimanfaatkan untuk mengetahui berapa batas jumlah barang dalam persediaan dengan memasukkan batasan jumlah barang minimal yang diinginkan. Dalam hal ini akan ada informasi yang memberitahukan tentang peringatan limit jumlah barang.

2. Saldo persediaan adalah menu yang bertujuan untuk mengetahui nilai persediaan baik dalam unit ataupun rupiah pada jangka waktu tertentu.

3. Supplier adalah menu yang digunakan untuk melihat daftar nama supplier atau pemasok.

4. Customer adalah menu yang digunakan untuk melihat daftar nama customer atau pelanggan.

5. Transaksi masuk adalah menu transaksi ini digunakan untuk melakukan pencatatan transaksi masuk (pembelian) terkait persediaan pada periode berjalan.

6. Transaksi keluar adalah menu yang digunakan untuk melakukan pencatatan transaksi keluar (penjualan) terkait persediaan pada periode berjalan.

7. Laporan adalah menu yang bertujuan untuk mengetahui laporan laba rugi bruto dari transaksi keluar masuk persediaan.

8. Keluar bertujuan untuk mengakhiri penggunaan aplikasi ini.

Sejak berlangsungnya pelatihan ini yang dimulai dari awal materi pertama kemudian diteruskan sampai pada materi kedua, dan terakhir pada saat sesi tanya jawab bahwa semua kegiatan ini terlaksana dengan cukup antusias. Para pembicara berusaha untuk melakukan pendekatan dengan para peserta pelatihan sehingga dapat dengan aktif berpartisipasi dan tertarik dengan materi pelatihan yang diberikan. 


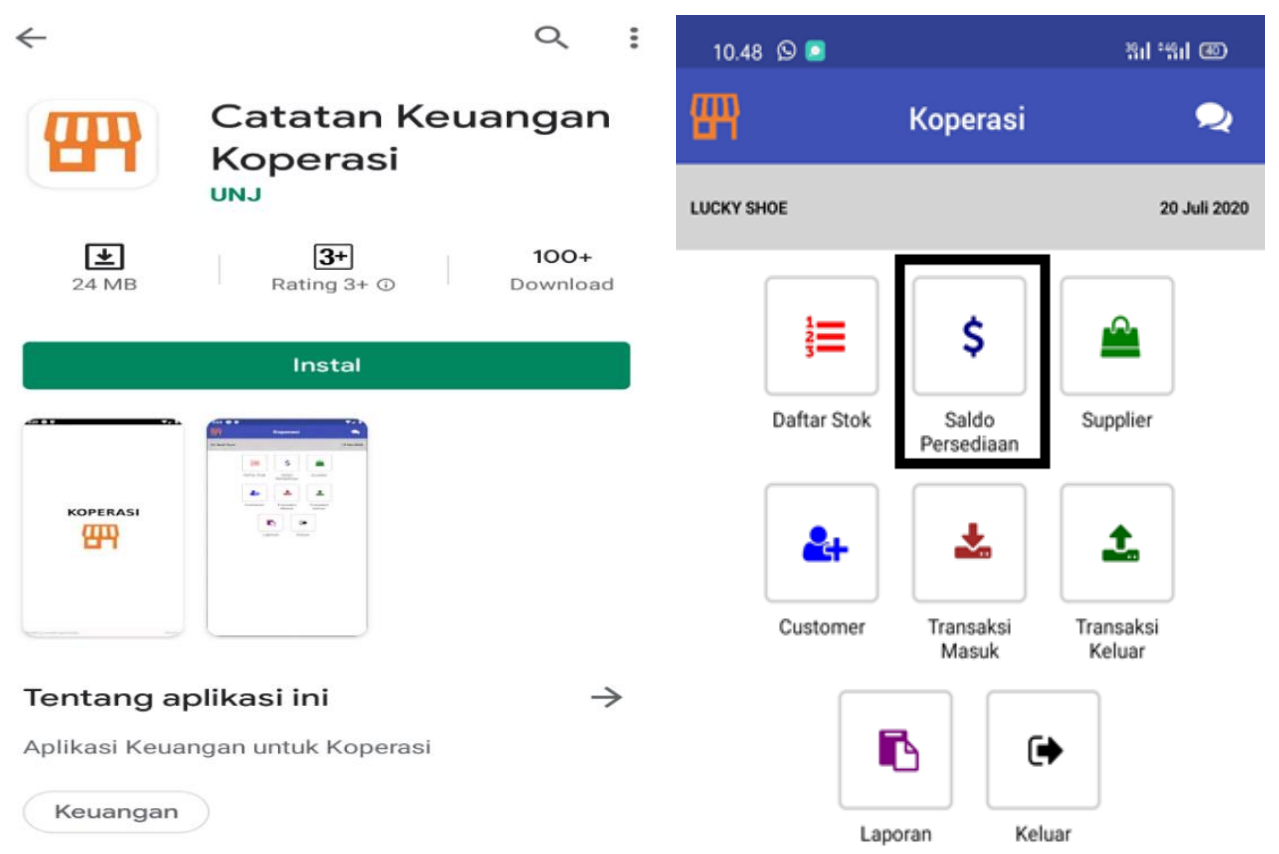

Gambar 2 Aplikasi catatan keuangan koperasi

Materi pada sesi 3 disampaikan melalui pencatatan persediaan menggunakan ms excelll. Pada sesi 2 ini membahas mengenai alternatif pencatatan persediaan selain menggunakan aplikasi berbasis android yang tidak jauh berbeda isi dari aplikasi ms excell ini yaitu meliputi data supplier, data customer, data produk, data transaksi dan laporan persediaan. Aplikasi menggunakan ms excelll ini sudah disediakan sehingga masing-masing peserta dapat mempraktikan materi secara mandiri dengan program yang sudah ada serta dapat disesuaikan daftar produknya dengan jenis usaha para pelaku usaha. Pada aplikasi ini dijelaskan tahapan-tahapan mengenai tahapan mengisi data usaha, daftar supplier (memasukkan, mengubah dan menghapus data), daftar customer (memasukkan, mengubah dan menghapus data), data produk (memasukkan, mengubah dan menghapus data), data transaksi masuk (pencatatan penerimaan), data transaksi keluar (pengeluaran jumlah persediaan barang dagang), dan laporan yang memuat data persediaan yang telah diinput secara periodik. Peserta diberikan contoh-contoh transaksi dan dilatih untuk membuat pencatatan persediaan menggunakan aplikasi ms excell ini. 


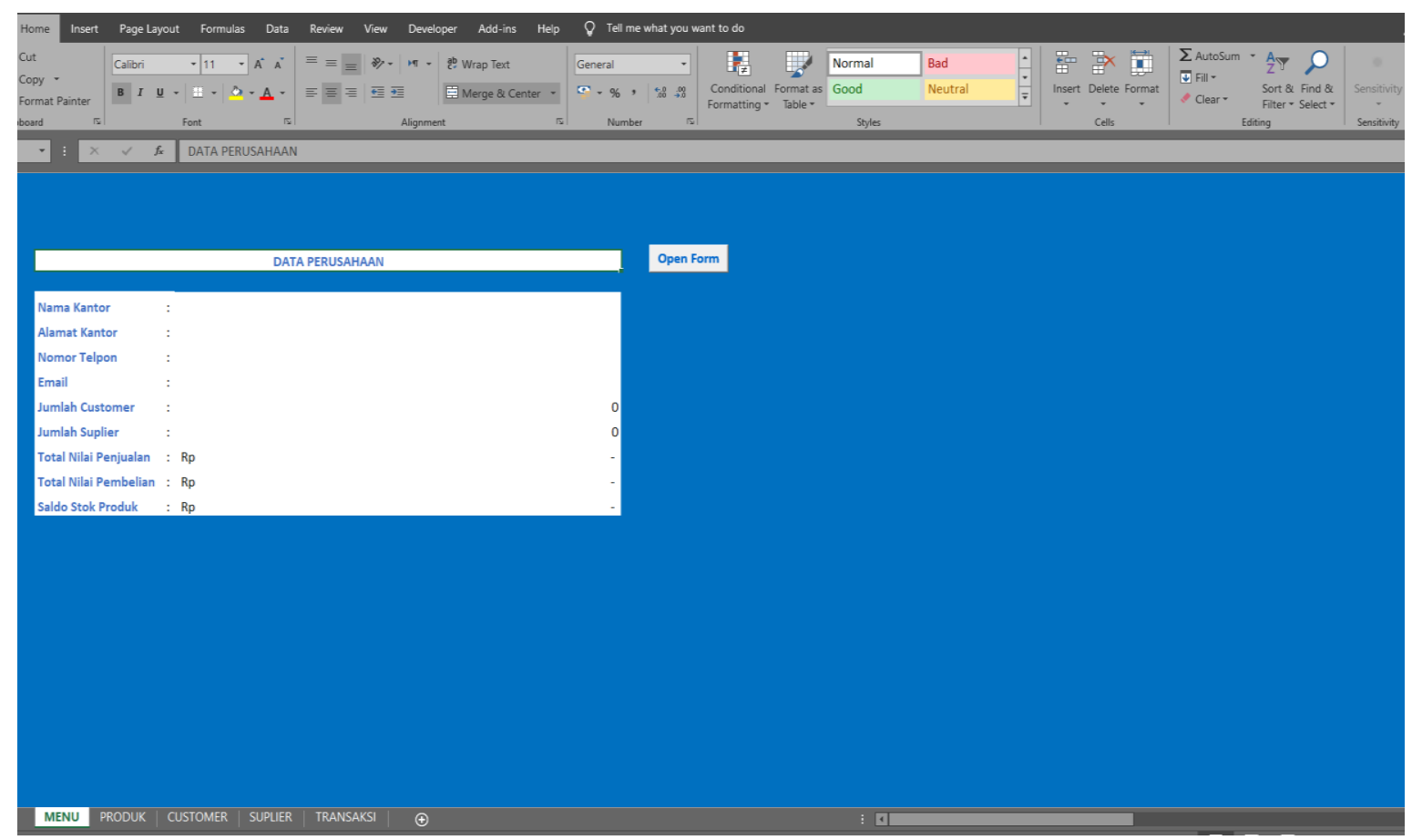

Gambar 3 Pencatatan Persediaan menggunakan Ms. Excelll

\section{Evaluasi Kegiatan}

Deskripsi Peserta Pengabdian pada Masyarakat

Dari lembar evaluasi yang diterima oleh panitia diperoleh umpan balik dari para peserta dengan jumlah peserta yang mengisi formulir evaluasi berjumlah 35 peserta dengan kuesioner yang terima sebesar 21 sebagai berikut:

Responden dalam pengabdian pada masyarakat ini adalah para peserta pelaku usaha koperasi dan UMKM pada saat pelaksanaan pelatihan ini. Adapun responden dikategorikan berdasarkan jenis kelamin adalah

Tabel 1. Responden Berdasarkan Jenis Kelamin

\begin{tabular}{llllll}
\hline & & Frequency & Percent & Valid Percent & Cumulative Percent \\
\hline Valid & LAKI-LAKI & 10 & 47,6 & 47,6 & 47,6 \\
& PEREMPUAN & 11 & 52,4 & 52,4 & 100,0 \\
& Total & 21 & 100,0 & 100,0 & \\
\hline
\end{tabular}

Tabel menunjukkan frekuensi dari total keseluruhan responden yang diklasifikasikan berdasarkan jenis kelamin. Sebanyak 35 peserta pelatihan yang merupakan para pelaku usaha diperoleh 11 responden adalah wanita dan 10 responden adalah pria. Berarti bahwa 50\% responden pria sama besar jumlahnya dengan responden wanita sebesar 50\%. Jika dilihat pada persamaan persentase yang mengikuti pelatihan pengabdian pada masyarakat tanggal 30 Juni 2021 bahwa dalam melakukan usaha tidak membedakan jenis kelamin baik laki-laki dan perempuan sama-sama berjuang dalam menghidupi perekonomian keluarganya dan kelangsungan usahanya. Hanya secara umum para laki-laki bersifat individualis, agresif, kurang sabar, lebih tegas, rasa percaya diri lebih tinggi dan lebih menguasai pekerjaan sedangkan perempuan cenderung lebih perhatian kepada orang lain, penurut, 
pasif, lebih mengedepankan perasaan dan mempunyai tanggung jawab mengurus keluarga yang lebih besar dari pada pria.

Tabel 2 Lama Usaha

\begin{tabular}{llllll}
\hline & & Frequency & Percent & Valid Percent & Cumulative Percent \\
\hline Valid & <1 TAHUN & 8 & 38,1 & 38,1 & 38,1 \\
& 1-3 TAHUN & 8 & 38,1 & 38,1 & 76,2 \\
& 4-6 TAHUN & 2 & 9,5 & 9,5 & 85,7 \\
& >6 TAHUN & 3 & 14,3 & 14,3 & 100,0 \\
& Total & 21 & 100,0 & 100,0 & \\
\hline
\end{tabular}

Tabel di atas menunjukkan bahwa responden dengan lama usaha antara $<1$ tahun sebanyak 8 orang, responden dengan lama usaha antara 1-3 tahun sebanyak 8 orang, responden dengan lama usaha 4-6 tahun sebanyak 2 orang, dan responden dengan lama usaha lebih dari 6 tahun sebanyak 3 orang. Lama usaha merupakan waktu yang sudah dijalani pengusaha dalam menjalankan usahanya. Lama usaha menentukan pengalaman, semakin lama usaha maka akan semakin baik kualitas usaha tersebut. Hal tersebut ditunjukkan bahwa mayoritas responden dengan lama usaha antara 1-3 tahun yang berarti terdapat banyaknya pengusaha baru di masa pendemi covid-19 dikarenakan pada kondisi pandemi ini memaksa masyarakat semua untuk mengisolasi diri di rumah dan tidak boleh keluar rumah supaya tidak terpapar virus corona ini. Hal ini memaksa membuat setiap orang harus menjadi kreatif dan memutar otak untuk mencari ide dan peluang usaha yang bisa dilakukan secara Work From Home.

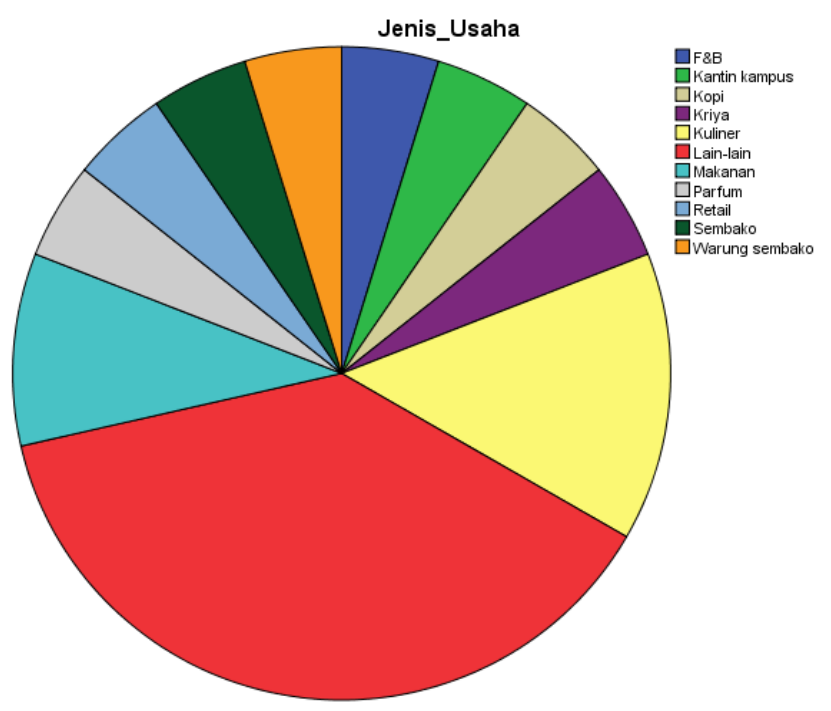

Gambar 4 Pie Chart Peserta Pelatihan berdasarkan Jenis Usaha

Berdasarkan karakteristik jenis usaha dapat dilihat bahwa sebagian besar usaha didominasi oleh pelaku usaha yang memiliki jenis usaha campuran atau lain-lain sebesar 8 responden dan selanjutkan usaha yang terbanyak kedua adalah usaha di bidang makanan yaitu 2 responden. Tidak dapat dipungkiri terlihat pada gambar diatas bahwa para pelaku usaha ini masih mencari-cari usaha yang cocok mereka jalani selama pandemic covid 19, dalam hal ini seperti diketahui rata-rata pelaku usaha memiliki lama usaha $<1$ tahun dan 1-3 tahun serta belum mempersiapkannya dengan matang 
untuk memulai usahanya terlihat dari jenis usaha lain-lain yang berarti masih mencari ide dan peluang usaha yang sedang marak dicari oleh khalayak ramai.

Dibawah ini rangkaian sesi bersama saat pelaksanaan pengabdian pada masyarakat pada tanggal 30 Juni 2021.

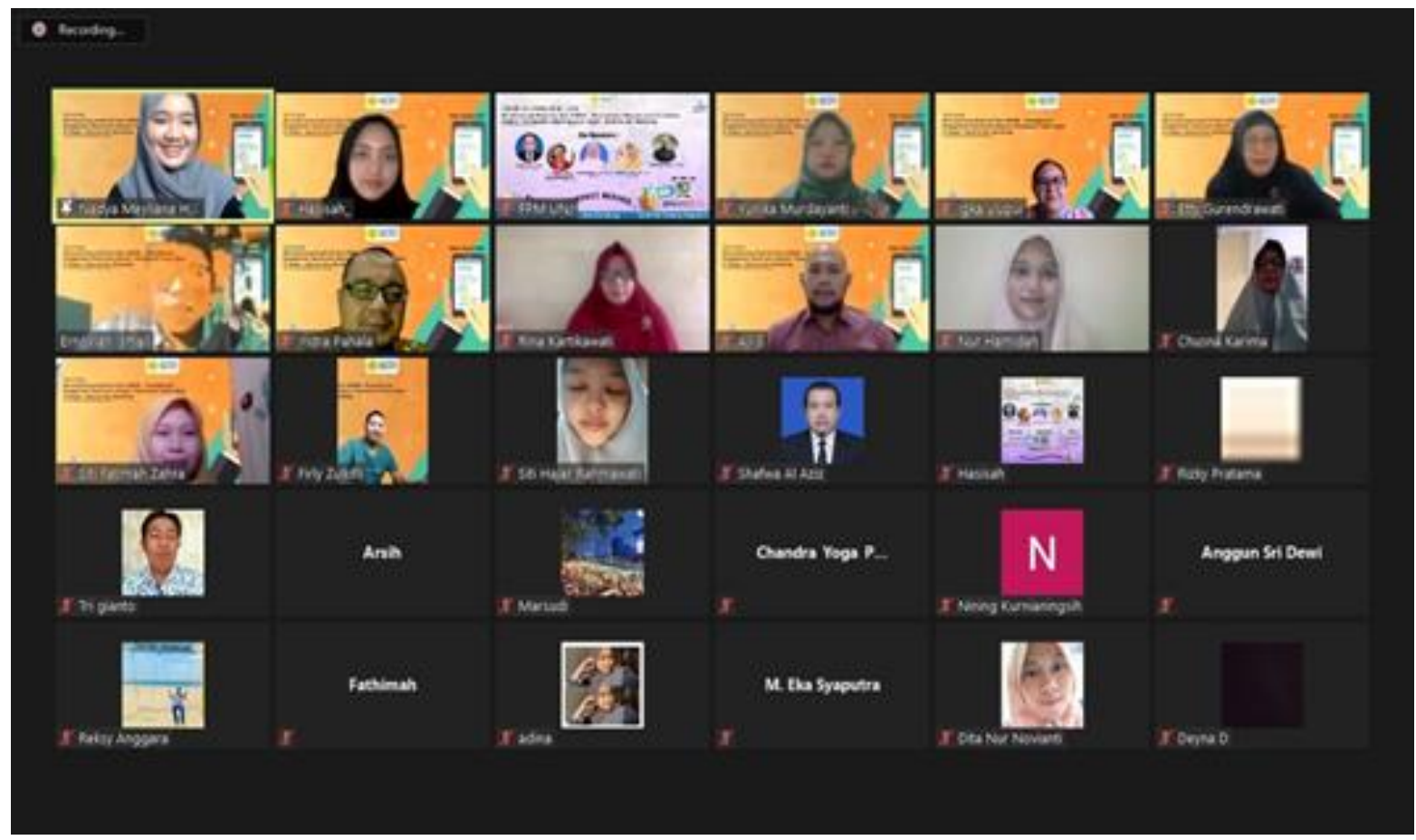

Gambar 5 Sesi Foto Bersama

Hasil Kuesioner

Dari hasil evaluasi dengan indikator pemahaman pencatatan persediaan, peserta merasakan manfaat dan ketertarikannya pada kejelasan pemaparan materi pelatihan, isi materi yang dipresentasikan dengan baik, mudah dimengerti dan diimplementasikan, materi yang disampaikan relevan dengan kebutuhan dan harapan peserta, serta alokasi waktu diskusi sudah cukup untuk memperkuat pemahaman peserta. Hasil evaluasi paling tinggi adalah pada pernyataan setelah mengikuti pelatihan tentang pencatatan persediaan, saya memahami prinsip untuk mencatat persediaan dengan rata-rata peserta menjawab sangat setuju, metode penyampaian materi pelatihan mampu menyampaikan materi pelatihan dengan baik dengan rata-rata peserta menjawab sangat setuju, dan Setelah mengikuti pelatihan tentang pencatatan persediaan, saya memiliki peningkatan keinginan untuk belajar (mempelajari lebih lanjut) mengenai prosedur pencatatan persediaan sesuai dengan prinsip akuntansi yang berlaku dengan rata-rata peserta juga menjawab sangat setuju. Dapat disimpulkan pada indikator pemahaman pencatatan persediaan dengan jawaban sangat setuju bahwa para peserta memiliki kemampuan memahami pencatatan persediaan menjadi dengan jelas, bisa mengikuti pentingnya prinsip persediaan demi kelangsungan usaha dan penguasaan para narasumber dalam menyajikan materinya sangat bermanfaat serta mampu dikuasai dengan baik oleh para peserta pengabdian pada masyarakat. Diketahui pula terdapat peningkatan kemampuan yang ditunjukkan dengan antusisme yang terjadi pada saat pelatihan dan respon dari evaluasi yang diberikan terkait kemudahan penggunaan teknologi informasi baik dengan penggunaan aplikasi berbasis android dan penggunaan ms. excell untuk dipraktekkan dalam pengelolaan persediaan koperasi dan UMKM disertai modul dan ppt materi yang sudah dibagikan sebelumnya, adapun rata-rata jawaban responden sangat setuju dan setuju sebagian besar terletak pada skala 4 dan 5. 
Dari hasil evaluasi dengan indikator minat belajar, peserta merasakan manfaat terhadap kejelasan pembicara dalam memberikan jawaban atas pertanyaan peserta dengan baik, penyampaian pembicara yang komunikatif dan menarik saat memberikan materi, serta informasi pelatihan yang disampaikan sangat jelas mulai dari info tanggal pelatihan sampai penutupan acara kegiatan. Hasil evaluasi tersebut terlihat dari pernyataan pada saya merasa sangat senang jika mendapatkan diskusi pelatihan pencatatan persediaan dengan rata-rata menjawab sangat setuju dan Saya merasa kecewa jika instruktur pelatihan pencatatan persediaan belum menyelesaikan materinya dengan jawaban yang diberikan juga sangat setuju. Berdasarkan angket yang disebarkan kepada para peserta diperoleh target peningkatan kemampuan SDM dalam pengetahuan mengenai ruang lingkup dan perkembangan koperasi dan UMKM dan simulasi praktik penggunaan aplikasi catatan keuangan koperasi dan aplikasi penggunaan ms.excell sebesar $80 \%$ tercapai. Dikarenakan respon pernyataan terkait ini menunjukkan tingkat respon yang tinggi dengan skala 4 dan 5, membuktikan bahwa instruktur mampu membagikan ilmu yang dimilikinya dengan sangat baik sekali.

Minat belajar ditandai dengan faktor emosional, faktor dari dalam diri dan faktor dari luar dirinya yang dapat mendorong para peserta dalam belajar (Atmaja et al., 2017; Haryati \& Feranika, 2020; Sulindawati \& Erni, 2017). Minat belajar ini sangat penting dalam keberhasilan para peserta pelatihan untuk meningkatkan pemahamannya terhadap persediaan menggunakan aplikasi ini demi ketertiban pencatatan dan menghindari adanya kesalahan mencatat pembelian dan penjualan barang dagang karena sistem yang digunakan masih manual.

\section{KESIMPULAN DAN SARAN}

1. Kesimpulan

Berdasarkan hasil pelaksanaan program pengabdian pada masyarakat ini dikemukakan kesimpulan sebagai berikut:

a. Pelatihan mengenai konsep dan teori dalam persediaan, para peserta merasakan manfaat dan ketertarikannya pada kejelasan pemaparan materi pelatihan, isi materi yang dipresentasikan dengan baik, mudah dimengerti dan diimplementasikan, materi yang disampaikan relevan dengan kebutuhan dan harapan peserta, serta alokasi waktu diskusi sudah cukup untuk memperkuat pemahaman peserta.

b. Berdasarkan angket yang disebarkan kepada para peserta diperoleh target peningkatan kemampuan SDM dalam pengetahuan mengenai ruang lingkup dan perkembangan koperasi dan UMKM dan simulasi praktik penggunaan aplikasi catatan keuangan koperasi dan aplikasi penggunaan ms.excell sebesar $80 \%$ tercapai dengan bukti dari jawaban responden dengan tingkat respon yang tinggi pada skala 4 dan 5, hal ini membuktikan bahwa instruktur atau narasumber mampu membagikan ilmu yang dimilikinya dengan sangat baik sekali.

c. Pelatihan pencatatan persediaan melalui aplikasi diketahui dari hasil kuesioner bahwa mempermudah para pengelola koperasi dan UMKM dalam membuat laporan laba rugi persediaannya dan melihat keuntungannya secara periodik.

2. Saran

Beberapa saran yang perlu diperhatikan yakni:

a. Pelatihan ini dapat dilakukan secara kontinue tidak hanya dari perguruan tinggi namun pemerintah setempat, industri dan NGO dapat melakukan pendampingan jangka sehingga 
diharapkan dapat menyelesaikan masalah - masalah yang berkaitan dengan manajemen dan akuntansi persediaan

b. Perlunya alternatif-alternatif aplikasi digital lainnya yang terus update sesuai perkembangan teknologi digital sesuai kebutuhan pelaku usaha sehingga mampu bersaing walaupun saaat ini menghadapi kondisi pandemi COVID 19.

\section{UCAPAN TERIMA KASIH}

Ucapan terima kasih disampaikan kepada Fakultas Ekonomi dan Lembaga Pengabdian Kepada Masyarakat Universitas Negeri Jakarta serta adik-adik mahasiswa yang telah bersedia menjadi penghubung pada para pelaku usaha dan koperasi.

\section{DAFTAR PUSTAKA}

Atmaja, R., Ramantha, I. W., \& Suartana, I. W. (2017). Pengaruh Minat Belajar Pada Pemahaman Akuntansi Dengan Kecerdasan Emosional Dan Kecerdasan Spiritual Sebagai Pemoderasi. E-Jurnal Akuntansi Universitas Udayana, 5(2017), 2021-2046.

Dolasinski, M. J., \& Reynolds, J. (2020). Microlearning: A New Learning Model. Journal of Hospitality and Tourism Research, 44(3), 551-561. https://doi.org/10.1177/1096348020901579

Haryati, D., \& Feranika, A. (2020). Pengaruh Pengendalian Diri, Motivasi, Perilaku dan Minat Belajar Terhadap Tingkat Pemahaman Akuntansi (Studi Empiris Pada Mahasiswa IAI Nusantara Batanghari dan Universitas Dinamika Bangsa Jambi). BIEJ: Business Innovation \& Entrepreneurship Journal, 4(2), 232-241.

Kader, M. A. (2018). Peran UKM dan Koperasi dalam Mewujudkan Ekonomi Kerakyatan Di Indonesia. JURISMA : Jurnal Riset Bisnis \& Manajemen, 8(1), 15-32. https://doi.org/10.34010/jurisma.v8i1.995

Lestari, D. F., \& Kholil, M. (2018). Efektifitas Pembinaan dan Pengawasan Koperasi Oleh Pemerintah Daerah (Studi di Dinas Perdagangan, Tenaga Kerja, Koperasi dan Usaha Kecil Menengah Kabupaten Karanganyar). Privat Law, 6(1), 46-59.

Mohammed, G. S., Wakil, K., \& Nawroly, S. S. (2018). The Effectiveness of Microlearning to Improve Students' Learning Ability. International Journal of Educational Research Review, 3(3), 32-38. https://doi.org/10.30659/e.1.1.68-75

Sari, D. I. (2018). Analisis Perhitungan Persediaan dengan Metode FIFO dan Average Pada PT. Harapan. $\begin{array}{lll}\text { Perspektif, } & 16(1), & 31-38 .\end{array}$ http://ejournal.bsi.ac.id/ejurnal/index.php/perspektif/article/view/2902/2058

Shail, M. S. (2019). Using Micro-learning on Mobile Applications to Increase Knowledge Retention and Work Performance: A Review of Literature. Cureus, 11(8). https://doi.org/10.7759/cureus.5307

Sulindawati, P. E. S. N. T. H., \& Erni, L. G. (2017). Pengaruh Kecerdasan Emosional Dan Minat Belajar Terhadap Tingkat Pemahaman Akuntansi Dengan Kepercayaan Diri Sebagai Variabel Pemoderasi (Studi Kasus Pada Mahasiswa S1 Akuntansi Universitas Pendidikan Ganesha). E-Journal S1 Akuntansi Universitas Pendidikan Ganesha, 7(1), 1-13. 